\title{
Commentary The long emergence of the infrastructure emergency
}

\begin{abstract}
Cities could not exist without infrastructure. Infrastructure provides a competitive advantage for those cities that have high quality facilities and high quality environments made possible by infrastructure. While the benefits of infrastructure are well known, the condition of infrastructure has been deteriorating for decades, precipitating crises and calls for action. This condition has been a long time in the making, due to structural reasons outlined herein. In addition, the complexity, cost and other factors have put politics and finance at the fore regarding infrastructure. As a consequence, planners have less of a purchase on infrastructure policy and strategy than in the past. Can planners recover their protagonism? What are key ideas that enable the urban planning profession to be at the forefront once again?
\end{abstract}

Keywords: infrastructure, planning, integration, finance, life cycle, cities, urban

Cities could not exist without infrastructure. Human settlements at the density of population and intensity of use that have been with us for millennia simply cannot function without infrastructure. How else to convey water, dispose of wastes, get around, communicate and so on? Infrastructure, then as now, always shaped and defined cities, both in fact and as icons. The London, Brooklyn and Golden Gate bridges; Victoria, Grand Central and Union stations; the Erie, Amstel, and Manchester canals, along with the canal networks that defined Amsterdam, Venice, Bangkok, Suzhou and a host of other cities - the list goes on. It is difficult to understand cities without knowing the invaluable, and inescapable, contributions of infrastructure. ${ }^{\mathrm{I}}$

In this era, population and economic growth, coupled with the accelerating pace and mobility of contemporary society, and changes in technology are among the major factors that drive the demand for new infrastructure networks and mega projects, as well as stress existing ones. New infrastructures are highly, and increas-

I Infrastructure refers to built facilities and networks - on, above or below ground and water - that support health, safety and welfare. This broad but not exhaustive take has traditionally included categories of systems such as:

- $\quad$ utilities - energy, water supply and sewerage, waste collection and disposal;

- $\quad$ public works - roads and bridges, dams and canals, ports and airports, railways;

- community facilities - prisons, schools, parks, recreation, hospitals, libraries;

- telecommunications - telephony, internet, television, satellites, cable, broadband, wireless, mobile, the cloud; and

- green infrastructures - interconnected networks of vegetated and riparian habitats: parks, rivers, corridors, swales, green roofs and walls and porous paving that provide ecosystem services.

Michael Neuman is Professor of Sustainable Urbanism at the University of New South Wales (UNSW), Built Environment, Australia; email: m.neuman@unsw.edu.au 
ingly, intensive with respect to energy, material, land, information and impacts, thus increasing their (our) aggregate footprint on Earth. Infrastructures make indelible and enduring imprints on cities, nature, people and wallets.

As cities compete in global arenas, they recognise that infrastructure provides a competitive advantage for those cities that have high quality facilities and services and high quality environments made possible by them (Miller, 2008; Erie, 2004; Lindstrom, 2002). There is hardly a government, global management consulting firm or industry association that has not produced a substantial report on urban infrastructure and competitiveness (United Kingdom Government, 20II; UNCHS, 20I3; ASCE, 2013; Productivity Commission, 2014; Price Waterhouse Coopers, 2012; ULI, 20II). There is good reason for this, as infrastructure is essential to cities, the economy and ecological health. Consider energy, provided by infrastructures that bind cities, the economy and the environment together. Urban areas consume energy and produce $\mathrm{CO}_{2}$ at a rate disproportionate to their population - with estimates ranging from 60 per cent to 75 per cent for energy use worldwide, compared to just over $5^{0}$ per cent of the global population (UNEP, 20I4; 20I2; Hammer et al., 20II). Of this energy, most is consumed by or through infrastructure: 25 to 30 per cent by transport and 35 to 40 per cent by buildings (that is, by the infrastructures that support them and their occupants). Thus, buildings and transport alone account for two-thirds of global energy consumption. As infrastructures in all their forms account for the majority of energy use and therefore carbon dioxide production in the city, getting infrastructure right is critical. Sustainable infrastructures are indispensible to attain sustainable cities, economies and societies. This is especially true in Organisation for Economic Co-operation and Development (OECD) nations, most of which have 75 to 90 per cent of their populations living in urban areas.

Yet the link between cities, sustainability and infrastructure goes far beyond energy and environment. The primary purpose of infrastructure networks and systems is to provide access to services. Yet, the benefits that accrue from access to infrastructure have a flip side. By providing and denying access, through both connecting and separating (segregating) users spatially, infrastructures play vital roles in producing equitable and just cities and societies (Graham and Marvin, 200I). International agencies, among others, call attention to this disparity (Narayan et al., 20I3; Partridge and Weinstein, 2013). Poor urban dwellers often have limited access and therefore limited opportunity, because slums, shanty towns and similarly impoverished or selfbuilt settlements tend to be underserved by infrastructure (Davis, 2006; UNCHS, 2008). Social and economic equity - always an implicit characteristic and outcome of infrastructure - needs to be made more explicit and visible in efforts to reduce growing inequalities (Piketty, 2014; Stiglitz et al., 2009).

Is burdening infrastructure with relieving poverty, improving slums and reducing inequality too much to ask? Other stressors on infrastructure capture high level atten- 
tion: the decline in public sector protagonism and tax revenues, the increase in public deficits and fewer resources to finance infrastructure. Where does shared prosperity fit amidst this cacophony? Can justice-oriented scholars and practitioners avoid these concerns? The accumulated deterioration of the physical condition of infrastructure, the attendant declines in the levels of service, rising inequality and environmental deterioration are the results. These outcomes have been long in the making.

At least as far back as America in Ruins - an analysis of the state of public works in the United States - studies have proclaimed the growing gaps between infrastructure needs and realities, and their dire consequences (Choate, I98I). A steady stream of reports from numerous sources around the world have been sounding the alarm. On aggregate, infrastructure conditions decline unabated (Porter et al., 20I4). This accumulated evidence has not led to significant institutionalised reforms that redress the problems, with the exceptions of privatisation and public-private partnerships. These latter two attend to socio-political shifts that have exploited the need for more private capital to fill public budget gaps and pay for infrastructure.

Yet private capital comes with costs, not least of which is its - along with the facilities it pays for - allegiance primarily to profit, rather than public health, safety and welfare, including equity and environmental concerns. The emphasis on shortterm financial return on investment also comes at the expense of long-term structural (governance) solutions to the long emergency of infrastructure. Is it any wonder that conditions keep deteriorating and inequalities keep growing? Accordingly, there is now a generalised erosion of confidence in all sectors to build and deliver basic services to society via infrastructure. These circumstances have given rise to the long emergency of infrastructure - one that shows no signs of abating.

\section{The infrastructure emergency is a long emergency}

The infrastructure emergency has been long in coming. It has had a long emergence. Moreover, the infrastructure emergency is a 'long emergency', meaning it burns on a slow fuse, with incremental effects that become manifest slowly over a long time (Kunstler, 2005). The problem with a long emergency, like the frog in water slowly simmering to a boil, is that incremental effects do not bring awareness and action. This is evident for infrastructure in at least two ways. First, out of sight, out of mind, at least till failure - the classic infrastructure conundrum. Second, most individuals and organisations are inured to a world of constant superlatives that announce incessant disasters, crises and emergencies. This is heightened by the always-on multimedia barrage of the $24 / 7$ news cycle. These factors serve to obscure the existence and very nature of the long emergency of infrastructure and thus hamstring effective reform.

In this way, governance is an inherent part of the long emergency, and its solution. Infrastructure was largely the province of government in the past. The current 
incapacity of the public sector to sufficiently meet its obligations with respect to infrastructure and related services has spawned a growing breach into which the private sector has leaped.

\section{Structural characteristics of the long emergency}

In order to solve the infrastructure governance equation, both government and infrastructures must be understood as quintessential technologies in the ontological sense, exposed by Heidegger (I977) in his essay 'The question concerning technology'. Technologies, according to Heidegger, transform all that they contact into a 'standing reserve' to be acted upon for instrumental benefit. These standing reserves are resources, including human resources, and thus units of production. That is, technology converts what it touches into instruments of production. Critically, he showed that the most prevalent of these technologies are bureaucracies and institutions (not only those of government) and their methods and procedures. Institutional procedures tend to reduce the art and science of judgements about complex infrastructure decisions to standardised formulae. A comment in this context is often heard in Sydney, Australia. Would the Opera House and Harbour Bridge, the two most iconic structures in the nation, have been built today if routine cost-benefit analysis (CBA) were to have been used? The implication being no, they would not.

In this context of how technologies of all kinds, including infrastructure and their governance institutions, transform their users, we can better comprehend other factors impinging on infrastructure that are structural in nature. Structural in this sense refers to the large-scale economic, social and political forces that are encoded into institutions and their procedures. Structural characteristics that affect infrastructure include:

- population and economic growth;

- increasing mobility of people, goods, information, capital;

- increasing speed of movement of people, goods, information, capital;

- growing size of cities;

- growing complexity of cities;

- increasing impacts of, and uncertainty due to, growing size and complexity;

- increasing global energy consumption, carbon dioxide production and climate change;

- increasing per capita costs and risks of infrastructure projects and networks;

- the telecommunications and networking revolutions that are underpinning many of these characteristics; and

- increasing neo-liberalism of politics, with reduced government, reduced taxes and revenues, increased deficits and debts. 
All of these have an impact on infrastructure planning, policy and financing. They are many, they are interrelated and they comprise abundant wicked problems. As these critical issues are matters of governance, they merit special attention.

The relation of infrastructure finance and politics has undergone a revolution in recent decades. The ascendance of finance capital in global cities and the networks that link and support them is one factor that conditions this relation (Sassen, 200I). Other factors include the neo-liberal shift transforming governance and the consequent changes in funding sources for, and ownership of, infrastructure - privatisation and partnerships being their most predominant forms. This shift has complicated the governance of infrastructure, once a more straightforward public sector enterprise, made the easier when cities were smaller and comprised a much higher portion of the metropolitan population. These changes have been occurring for quite some time. Storper's analysis of metropolitan governance reminds us that scholars have been reporting that the metropolis is 'ungovernable' since at least the I950s (Storper, 20I4).

This long trajectory of changing structural features of society, triggered by the advent of post-industrial globalisation and the networking of society, has yielded a genuine transformation of our cities and the way in which they are designed, built and managed. These changes are especially notable in the infrastructure sectors. Yet our governance structures have not kept pace and by and large remain conditioned by centuries' old institutions, such as the municipal corporation and the nation-state. Again, is it any wonder that we are now saddled with crumbling infrastructure and declining service levels?

\section{Governance}

The contributors to this issue highlight the complexity of infrastructure today, particularly its management and governance. The number of jurisdictions at several levels of government in a single metro area or city region - typically uncoordinated and often competing - complicates strategy formation, planning policy and service delivery. Even an analytical tool as ostensibly straightforward as cost-benefit analysis is fraught with problems in application and limited in its capacity to inform decisions in a conclusive manner (Laird et al., 20I4 (this issue)). What follows is a brief sketch of the relations among infrastructure and its planning, financing and governing using two tools to illustrate.

Some of today's infrastructure management tools are antiquated, such as costbenefit analysis (CBA) and environmental impact assessment (EIA). They are being replaced by new tools, such as combined risk and cost-benefit analysis (NRC, 20I4) and life cycle assessment (Neuman, 20I Ia). The question is not merely how to improve or better use these and other tools. Rather, the question is how to align the new tools - the province of technocrats and professionals - with money and power - the 
province of politics and finance and the governors of infrastructure decisions, without compromising on the health, safety and welfare values of the past and sustainability values of today, including social equity and environmental integrity. Speaking truth to power or connecting knowledge to action is not enough in an era where governments act against, or in disregard of, facts and evidence.

A technocratic approach addresses performance outcomes. Its criteria, however, need to be aligned with the ways and means of finance and politics. What are the most effective institutional structures and processes to allow for the innovation, financing and building of infrastructures that perform sustainably, equitably and affordably? What are the barriers to their adoption? These are essential questions for research and practice.

One performance-oriented method is life cycle assessment (LCA), when linked to levels of service. LCA is an analytical tool used to measure long-term value. When referred to as 'cradle to grave' or 'well to wheel', it imparts the sense of a long-term accounting of input and output factors, including downstream impacts and embodied energy. LCA can be applied to a single case or comparatively across choices and scenarios. While different methods are emerging and applications are increasing, LCA is extraordinarily data intensive, thus limiting its use. Its use is made more difficult because most accounting and inventory systems were not designed with LCA data needs in mind.

Any valid life cycle approach for urban infrastructure and its planning must answer the following question: what are the most effective methods and models to measure and project future scenarios for the full sustainability of infrastructures, including embodied energy and carbon, comprehensive economic and environmental impacts, and social equity?

While the full implications of an answer for this question is beyond the scope of this commentary much less virtually all statutory planning systems, a more encompassing life cycle approach - life cycle planning - starts with a life cycle assessment and continues through the entire governance life cycle of planning, programming, designing, costing, budgeting, financing, building, operating, maintaining, rehabilitating, replacing and repurposing/recycling; back to the beginning of the cycle, evaluating or assessing (Neuman, 20ria). Truncated versions have been employed, including build-operatetransfer (BOT), build-operate-own-transfer (BOOT) and others (World Bank, 2004). The ideal that life cycle approaches aspire to, however, is far from the realities of practice (Neuman and Whittington, 2000) (see Figure I).

An explosion of studies and reports that employ life cycle methods for infrastructure, by consulting firms, professional peak bodies, government, non-profits and non-governmental organisations and researchers suggest that infrastructure assessment is a hot topic. While they have different purposes, data, methods, findings, conclusions and recommendations, the overwhelming sense one gets when reading 


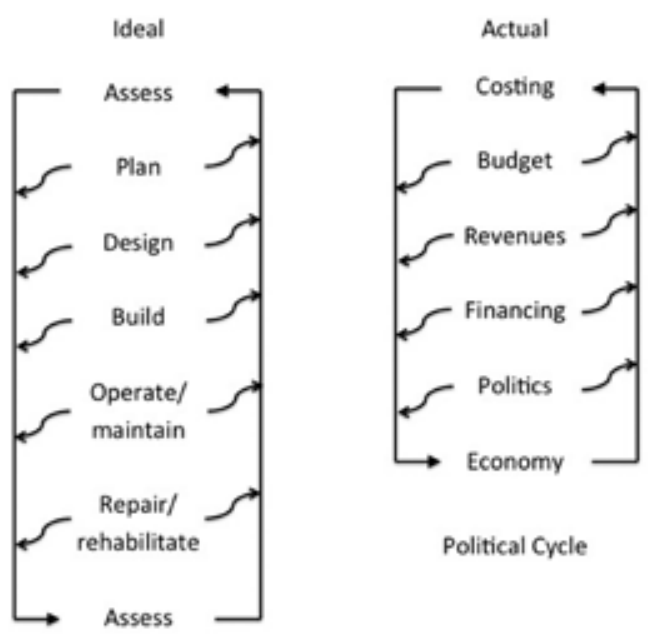

Figure 1 Infrastructure

life cycles.

Source: Neuman and

Whittington $(2000,84)$.

Life Cycle

them is that while on the one hand infrastructures of all kinds are critical to the proper functioning of society, economies, cities and ecosystems, on the other hand their current conditions and future prospects are dire. 'Report cards', Infrastructure Needs Assessments and the like reveal or suggest failing marks and trillions of dollars of deficits relative to prescribed or desired levels of service.

\section{Finance and politics}

Notwithstanding, the most consequential matters regarding infrastructure provision today are not 'mere' governance and management, at least as conceived in prevailing scholarship. The most important factors are politics and finance, always coupled. This is especially true today, as campaign financing conditions politics, especially from private developers at the local level. Finance and politics govern the willingness and wherewithal to get infrastructure built and to fund its operations and maintenance.

Examples of the intertwined imperatives of politics and finance abound. Here are three to illustrate. First, California's 'golden years' of the ig6os were propelled by massive investments in a triad of strategic infrastructures: higher education, water and transport that led to a decades-long ascendance in American and global contexts in terms of productivity and innovation, not to mention growth (Neuman and Whittington, 2000). Second, in Los Angeles, the infrastructures of water, power, seaport and airport have once again reasserted their pivotal roles in the city's development. This has led to characterising this infrastructure-urban development nexus in LA as a 'developmental city-state' (Erie, 2004, 30). Third, in the state of New 
South Wales, Australia, the Treasury Minister for the state has become Premier and has pledged to be the 'infrastructure premier', after focusing his tenure as Treasurer squarely on infrastructure privatisation and road construction. This is in tune with Australia's Prime Minister proclaiming himself the 'infrastructure prime minister' (Norington, 2014; Abbott, 2013).

The three cases above span fifty years. They illustrate exactly how the profound change in politics from a belief that the government can serve the public good to a strong neo-liberal belief that markets can do better than the government has affected the financing, provision and beneficiaries of infrastructure. These changes have had an important impact on taxation, government budgets and infrastructure financing.

While the politics-finance conjunction is easy to identify, current practices of infrastructure finance are beginning to tackle thorny issues, such as public risk and value capture, much less derive permanent and long-term solutions in political and economic (and thus bureaucratic) cultures mired in short-term ones. While there is an abundance of ways to finance infrastructure when they are single projects and/ or have limited time horizons, new types of financing are needed that are sustainable both financially and economically in the long run (fifty years and more). They need to answer some fundamental questions, until recently foreign to standard infrastructure finance decision processes: what aspects of private risk assessment can be adapted for the public sector and public-private partnerships that are not indebted to the pure profit motive? What are the most effective mechanisms to finance infrastructure in a tax constrained environment? Is there a life cycle approach to financing that goes beyond the traditional financing that is largely limited to the initial capital investment to fund the entire life cycle over the long term? Can urban planning be a guide to improve the current state of affairs in infrastructure?

\section{Planning and leadership}

Unlike cities themselves, that evolve and develop via a combination of government, market and other forces of spatial production by which intentional city planning can take a subordinate role; infrastructure systems are always planned and designed and exert a profound and pervasive influence on the shape and growth of cities. This puts a premium on the planning and design of infrastructures in the realm of urban planning and design and their integration into the urban fabric. Yet infrastructure was almost a forgotten topic in urban planning (Neuman and Smith, 2010), until a recent resurgence in some quarters (Marshall, 20I4). Have planners and designers abdicated their traditional roles in building cities through infrastructure? Who has taken their place? Can planners and designers recapture their squandered protagonism?

How relevant are the historical roots of planning in infrastructure in an intensely neo-liberal era? Health, safety and welfare were traditional justifications for infrastruc- 
ture, planning and government intervention. How valid are they today? Nowadays, infrastructure manifests itself in more instrumental and more limited ways, such as to increase economic productivity and competitiveness. Economic criteria and methods are more likely to be applied to scrutinise proposals and evaluate performance.

This was not always so. The iconic urban plans prior to the industrial revolution were street layouts with parks and squares interspersed. In the modern, industrial era, seminal city plans were based on infrastructure. Haussmann in Paris integrated street reforms with drainage and provided for other facilities. Cerdà in Barcelona went several steps further by integrating sewers and water supply into the street or storm drainage grid. He also provided for the first underground metro system (not built) and, most significantly, integrated infrastructures seamlessly into the built fabric of the new city extension (Neuman, 20i ib).

These pioneer engineer-planners set the mould for modern planning by demonstrating that infrastructure was strategic in transforming a city and by offering models for how to attain sustainability and productivity at the same time - namely, by integrating infrastructure networks. Hall's historical survey (I988) identified infrastructure as a pillar of early urban planning, as have others (Reps, I965; Choay, I969; Benevolo, ig8o).

Today, infrastructure integration is the resurgent watchword as a key strategy for sustainable urbanism. Which forms and means of network integration are the most sustainable and affordable? How to best integrate infrastructure networks amongst each other, in order to interconnect them so that the output of one becomes the input of another, thus avoiding waste and duplication? How to best integrate infrastructure networks into the urban fabric (Pandis Iveroth et al., 20I3; McDonough and Braungart, 2002)? These principles provide opportunities for urban planners and policymakers, along with related built environment disciplines, to re-establish their authority (Neuman, 2009).

The challenge that planning leadership entails is not without its challenges. Regarding infrastructure, one of these is its escalating cost. They are extremely high and rising on both absolute and per capita bases, placing decisions about them firmly in the hands of financiers. It is therefore critical that they be planned and designed to reduce their costs. Recent evidence suggests that per capita costs for networked infrastructures are increasing, owing to their growing scale and complexity, fuelled by advances in technology and increases in labour, material and energy costs. This goes against the neo-classical economic precept of economies of scale, which when applied to urban infrastructure suggests the opposite (Álvarez et al., 2014; Dittrich-Wesbuer et al., 20I4).

The inertia generated by the enormous sunk costs in capital investments serves to slow the pace of necessary change, both in infrastructures themselves, as well as their governance. Large-scale, centralised systems are slowly giving way to distrib- 
uted, decentralised and smaller scale networks. In the future, these latter configurations may prove to be more adaptable to the fluid and emergent configurations of city regions and necessary for both sustainability and cost reasons. Doing more with less and mimicking nature are other paths to more affordable, sustainable and governable infrastructure in the future. We can strive to integrate infrastructure networks with each other and their urban places, in order to reduce costs, impact and waste. We can go further by reducing overall infrastructure demand and increasing its sustainability simultaneously, especially for mobility, stimulated by the adage: 'The 2oth Century was about getting around. The 2 ist Century will be about staying in a place worth staying in' (Kunstler, n.d.). Infrastructure is key to making places worthwhile.

\section{References}

Аввотт, А. (2013), 'Election speech' (speech delivered at Brisbane, 25 August). http://electionspeeches.moadoph.gov.au/speeches/20I3-tony-abbott (accessed 2 September 20I4).

Álvarez, I., PRIETO, A. and zofío, J. (2014), 'Cost efficiency, urban patterns and population density when providing public infrastructure: a stochastic frontier approach', European Planning Studies, 22, I235-58.

ASCE (AMERIGAN SOCIETY OF CIVIL ENGINEERS) (20I3), 'America's Infrastructure Report Card 2013' (official report card), Washington, DC, ASCE.

Benevolo, L. (1980), The History of the City, Cambridge, MA, MIT Press.

ChoAte, P. (I98I), America in Ruins: Beyond the Public Works Pork Barrel, Washington, DC, Council of State Planning Agencies.

GHOAY, F. (I969), The Modern City: Planning in the Igth Century, New York, NY, George Braziller. DAVIs, M. (2006), Planet of Slums, London, Verso.

DitTriah-wesbuer, A., MAYR, A. and schulwitz, M. (20I4), 'Conflictive demands to urban (waste-)water infrastructure in the face of demographic change, climate change and strategic urban planning' (paper delivered at the Association of European Schools of Planning congress, Utrecht, July).

ERIE, s. (2004), Globalizing LA: Trade, Infrastructure, and Regional Development, Stanford, CA, Stanford University Press.

GRAHAM, S. AND MARvin, s. (200I), Splintering Urbanism: Networked Infrastructure, Technological Mobilities, and the Urban Condition, London, Routledge.

Hall, P. (1988), Cities of Tomorrow: An Intellectual History of Urban Planning and Design in the Twentieth Century, New York, NY, Basil Blackwell.

hammer, S. A., KeIRSTEAD, J., DHAKal, s., Mitchell, J., GOlley, M., GONNELl, R., GONZALEZ, R., Herve-mignugGi, M., PARshall, L., schulz, N. AND hyams, M. (2Oi I), 'Climate change and urban energy systems', in C. Rosenzweig, W. D. Solecki, S. A. Hammer and S. Mehrotra (eds), Climate Change and Cities: First Assessment Report of the Urban Climate Change Research Network, Cambridge, Cambridge University Press, 85-II .

HeIDEgGer, M. ([I954] I977), 'The question concerning technology', in M. Heidegger, The 
Question Concerning Technology and Other Essays, trans. William Lovitt, New York, NY, Harper \& Row, 3-35.

KUNSTLER, J. (N.D), WWW.PPS.ORG/REFERENGE/JHKUNSTLER/ (accessed 2I January 20I4). Kunstler, J. (2005), The Long Emergency: Surviving the End of Oil, Climate Change, and other Converging Catastrophes of the Twenty-first Century, New York, NY, Grove Press.

Lindstrom, в. (2002), 'Public works and land use: the importance of infrastructure in Chicago's metropolitan development, I830-1970', in W. Weiwel and J. Persky (eds), Suburban Sprawl: Private Decisions and Public Policy, Armonk, NY, M. E. Sharpe, 3-24.

marshall, T. (2014), 'The European Union and major infrastructure policies', European Planning Studies, 22, I484-506.

madonough, w. And braungart, м. (2002), Cradle to Cradle: Remaking the Way We Make Things, New York, NY, North Point Press.

MILlER, J. (2008), 'Infrastructure 2008: A Competitive Advantage' (ULI and Ernst \& Young report), Washington, DC, Urban Land Institute.

NARAYAN, A., SAAVEDRA-CHANDUVI, J. AND TIWARI, s. (20I3), 'Shared Prosperity: Links to Growth, Inequality and Inequality of Opportunity' (Policy Research Working Paper No. WPS 6649), Washington, DC, World Bank.

Neuman, M. (2009), 'Spatial planning leadership by infrastructure', International Planning Studies, I4, $20 \mathrm{I}-\mathrm{I} 7$.

neuman, m. (20IIa), 'Infrastructure planning for sustainable cities', Geographica Helvetica, I5, IOO-7.

NEuman, M. (20 I Ib), 'Ildefons Cerdà and the future of spatial planning: the network urbanism of a city planning pioneer', Town Planning Review, 82, I 7 -43.

NEUman, M. AND SMith, s. (2010), 'Infrastructure and city planning: once and future partners', Journal of Planning History, 9, 2I-42.

neuman, m. And whittington, J. (2000), Building California's Future: Current Conditions in California's Infrastructure Planning, Budgeting and Financing, San Francisco, CA, Public Policy Institute of California.

nORIngton, в. (20I4), 'Accidental Premier Mike Baird sees first ioo days flash past', The Australian, 26 July. http://www.theaustralian.com.au/national-affairs/accidental-premier-mikebaird-sees-first-Ioo-days-flash-past/story-fn59niix-ı227001992516 (accessed 2 September 20I4).

NRG (National Research council) (2014), Reducing Coastal Risks on the East and Gulf Coasts, Washington, DC, The National Academies Press.

PANDIS IVEROTH, S., VERNAY, A-L., MULDER, K. AND BRANDT, N. (2OI3), 'Implications of systems integration at the urban level: the case of Hammarby Sjöstad, Stockholm', fournal of Cleaner Production, 48, 220-31.

PARTRIDGE, M. AND WEINSTEIN, A. (2013), 'Rising inequality in an era of austerity: the case of the

US', European Planning Studies, 21, 388-410.

PIKetty, т. (2014), Capital in the Twenty-First Century, Cambridge, MA, Belknap Press. PORTER, M., STERn, s. AND GREEN, M. (20I4), 'Social Progress Index 20I4' (index), Washington,

DC, Social Progress Imperative.

Price WATERhouse COOPERs (2012), Cities of Opportunity, New York, NY, Price Waterhouse Coopers. 
PRoductivity commission (2014), 'Public Infrastructure' (draft inquiry report), Canberra, Australian Government. RePs, J. (1965), The Making of Urban America: A History of City Planning in the United States, Princeton, NJ, Princeton University Press.

sassen, s. (200I), The Global City, Princeton, NJ, Princeton University Press.

Stiglitz, J., SEN, A. AND fitoussi, J-P. (2009), 'Report by the Commission on the Measurement of Economic Performance and Social Progress' (report), Paris, GDP Commission.

storper, m. (20I4), 'Governing the large metropolis', Territory Politics and Governance, 2, I I5-34. Uli (THE URban LAND institute) (20II), 'Infrastructure 20II: A Strategic Priority' (strategic report by ULI and Ernst \& Young), Washington, DC, Urban Land Institute.

unchs (United nations centre for human SetTlements) (2008), State of the World's Cities 20I0/20II: Bridging the Urban Divide, Nairobi, UNCHS, and London, Earthscan.

unchs (united nations centre For human settlements) (2013), Planning and Design for Sustainable Urban Mobility: Global Report on Human Settlements 2013, Nairobi, UN Habitat.

UNEP (United Nations environment programme) (2012), 'Global Environmental Outlook GEO 5' (assessment report), Nairobi, UNEP.

UNEP (UNITED NATIONS ENVIRONMENT PROGRAmME) (2014), UNEP Year Book 20I4, Nairobi, UNEP. UNITED KINGDOM GOVERNMENT (20I I), 'National Infrastructure Plan 20I I' (policy paper (revised)), London, HM Treasury and Infrastructure UK.

WORLD BANK (2004), 'Reforming Infrastructure: Privatization, Regulation, and Competition' (policy research report), Washington, DC, World Bank. 